\title{
Faktor - faktor yang Mempengaruhi Pendapatan Toko Kelontong di Kabupaten Aceh Utara
}

\author{
Nurlisa
}

Institut Agama Islam Negeri Lhokseumawe

\section{Suryani}

Institut Agama Islam Negeri Lhokseumawe

suryapijar@yahoo.com

\section{Ismaulina}

Institut Agama Islam Negeri Lhokseumawe ismaulina@gmail.com
Abstrak
Penelitian ini bertujuan menganalisis baik secara parsial dan simultan pengaruh faktor modal dan lokasi terhadap pendapatan toko kelontong di Kabupaten Aceh Utara. Analisis kuantitatif diperoleh dari data primer melalui penyebaran kuesioner kepada responden penelitian sebanyak 73 pedagang. Kesimpulan yang didapatkan menunjukkan hasil secara simultan modal dan lokasi terbutkti signifikan mempengaruhi pendapatan, sedangkan secara parsial hanya modal yang berpengaruh signifikan

\section{Kata Kunci Kualitas layanan, persepsi harga, cita rasa, dan kepuasan konsumen.}

\section{PENDAHULUAN}

Tolak ukur untuk menunjukkan tingkat pembangunan ekonomi suatu daerah bisa diidentifikasikan dari pertumbuhan ekonomi suatu daerah, dengan kata lain pertumbuhan ekonomi dapat memperlihatkan adanya pembangunan ekonomi. Pelaksanaan pembangunan bidang ekonomi dimaksudkan untuk mewujudkan pemerataan hasil dimana salah satu sektor di bidang ekonomi tersebut adalah industri kecil.

Pembangunan pada sektor industri kecil atau usaha mikro kecil dan menengah diarahkan agar mampu berkembang secara mandiri untuk meningkatkan pendapatan masyarakat. Namun demikian, industri kecil dalam perkembangannya masih menghadapi berbagai persoalan yang perlu mendapat perhatian dari berbagai pihak, antara lain meliputi rendahnya produktivitas dan sumber daya manusia, manajemen yang belum profesional, kurang tanggap terhadap perubahan teknologi dan kurangnya permodalan.

Pengembangan Usaha Mikro Kecil dan Menengah (UMKM) merupakan salah satu upaya dalam perbaikan perekonomian nasional, karena sebagian besar usaha di Indonesia adalah usaha kecil dan menengah yang banyak menyerap tenaga kerja dan memanfaatkan sumber daya domestik. 
Pedagang sebagai bagian dari sektor informal merupakan lahan pekerjaan yang terbuka bagi siapapun. Peningkatan Pendapatan Asli Daerah (PAD) disisi lain bisa dimanfaatkan dari keberadaan pasar sebagai salah satu sumber keuangan. Dengan kapasitasnya yang besar untuk menyerap pedagang, dan mewadahi lalu lintas uang yang terus bergerak dinamis dari hari ke hari, maka keberadaan pasar menjadi sangat strategis untuk terus dikembangkan.

Istilah pasar dewasa ini dikategorikan kedalam pasar tradisional dan pasar modern. Hal mendasar yang membedakan keduanya adalah proses interaksi dan pola pengelolaan atau manajemen antara keduanya. Pasar tradisional yang pada umumnya dimiliki oleh pemerintah, terjadi interaksi langsung antara penjual dan pembeli, dengan proses tawar menawar. Sementara pasar modern, pada umumnya pembeli melakukan kegiatan secara swalayan, atau terdapat pramuniaga, dan sistem pembelian dilakukan dengan harga yang sudah ditetapkan, terdapat label harga. Pasar modern diantaranya adalah pertokoan, mall, plaza, hipermarket, supermarket dan minimarket. Minimarket modern yang memang dilengkapi fasilitas yang mmadai seperti pendingin ruangan, sistem pembelanjaan yang swalayan, harga barang yang sudah pasti, serta konsumen bisa menggunakan pembayaran non-tunai membuat konsumen lebih tertarik untuk berbelanja ke minimarket modern. Hal tersebut bertolak belakang dengan toko kelontong, mengingat fasilitas yang diberikan masih minim, sistem pembelanjaan masih bersifat konvensional, dan pembayaran yang harus tunai.

Pasar tradisional memiliki keunggulan yang tidak dimiliki oleh pusat perbelanjaan modern yaitu adanya sistem tawar menawar yang menunjukkan keakraban antara penjual dan pembeli. Sistem tawar menawar dalam transaksi jual beli di pasar tradisional membuat suatu hubungan tersendiri antar penjual dan pembeli. Berbeda dengan pusat perbelanjaan modern, dimana harga barang sudah ditetapkan dan tidak ada komunikasi antara penjual dan pembeli.

Meskipun demikian, kelemahan yang dimiliki pasar tradisional dan telah menjadi karakter dasar mulai dari faktor desain, tata ruang, tata letak, dan tampilan yang tidak sebaik pusat perbelanjaan modern, alokasi waktu operasional yang relatif terbatas, kurangnya teknologi yang digunakan, kualitas barang yang kurang baik, kurangnya promosi penjualan, rendahnya tingkat keamanan, kesemrawutan parkir, hingga berbagai isu yang merusak citra pasar tradisional seperti maraknya informasi produk barang yang menggunakan zat kimia berbahaya, praktek penjualan daging oplosan, serta kecurangan-kecurangan lain dalam aktivitas penjualan dan perdagangan. Kompleksitas kelemahan pasar tradisional tersebut menyebabkan konsumen beralih dari pasar tradisional ke pusat perbelanjaan modern.

Keberadaan pasar, khususnya yang tradisional, merupakan salah satu indikator paling nyata kegiatan ekonomi masyarakat di suatu wilayah. Sejatinya pasar tradisional memiliki keunggulan bersaing alamiah yang tidak dimiliki secara langsung oleh pasar modern. Lokasi yang strategis, area penjualan yang luas, keragaman barang yang lengkap, harga yang rendah, sistem tawar menawar yang menunjukkan keakraban antara penjual dan pembeli merupakan keunggulan yang dimiliki oleh pasar tradisional. 
Salah satu faktor penting dalam mengelola suatu usaha adalah modal. Sebelum relokasi modal yang dibutuhkan hanya untuk membeli dagangan baru agar dapat menarik para pembeli dan menambah dagangan. Setelah adanya relokasi ada beberapa para pedagang yang menginginkan kios yang lebih luas dan di dekat jalan harus menambah modal untuk membayar sewa yang lebih. Sedangkan para pedagang yang tetap dengan kios yang telah ditentukan juga membayar sewa walaupun tidak sama dengan para pedagang yang lain. Karena harga sewa yang diberikan sesuai dengan ukuran kios.

Selain faktor modal, faktor yang mempengaruhi keberhasilan para pedagang dalam menjual dagangannya adalah lokasi berdagang, semakin strategis lokasi semakin memudahkan para pedagang menjual barang dagangannya. Sementara itu pendapatan merupakan faktor penting bagi pengusaha toko kelontong demi menjaga kelangsungan usaha mereka. Hasil dari usaha yang mereka peroleh nantinya dapat digunakan untuk kebutuhan sehari-hari dan biaya usaha mereka ke depannya. Apabila jumlah pengunjung toko kelontong dan keuntungan dari usaha mereka berkurang maka timbul dampak pada kelangsungan usaha toko kelontong tersebut atau bahkan sampai ada yang menutup usahanya. Setelah usaha dimulai, yang diperlukan suatu usaha agar dapat berjalan lancar dan berkembang adalah pengelolaan yang baik.

Berdasarkan penelitian yang dilakukan oleh Deputi Bidang Pengkajian Sumberdaya UKMK, Kementerian Koperasi dan UKM dengan PT Solusi Dinamika Manajemen (2005) menyebutkan semakin tinggi omzet penjualan yang diperoleh maka semakin tinggi pendapatan yang didapatkan. Variabel perubahan omzet penjualan pada penelitian tersebut menunjukkan perbedaan signifikan yang didapat dari sebelum adanya alfamart dan setelah adanya alfamart di sekitar toko kelontong.

Pertumbuhan waralaba modern seperti Indomaret dan Alfamart sangat pesat menyebar hampir seluruh wilayah di Indonesia. Toko-toko modern hampir dapat ditemui di setiap wilayah-wilayah daerah tertentu dan bahkan saling berhampitan antar perusahaan yang membelakanginya. Setiap tahun gerai Indomaret maupun Alfamart terus bertambah bahkan setiap tahun tidak pernah berkurang jumlahnya, namun dibalik data tersebut tidak semua kepemilikan dimiliki secara penuh oleh perusahaan ada sekitar 50\% di antaranya adalah gerai tersebut milik pewaralaba.

Melihat keadaan pertumbuhan waralaba minimarket/gerai toko modern seperti Indomaret maupun Alfamart yang dikuasai oleh sebuah perusahaan tertentu jelas menimbulkan efek atau dampak bagi pengusaha toko kelontong di daerah yang dijamuri oleh toko modern tersebut. Jarak antara toko kelontong dengan alfamart juga akan berpengaruh terhadap perubahan pendapatan pedagang tradisional atau pedagang kelontong. Jarak kedekatan berdirinya minimarket dengan toko kelontong berpengaruh positif terhadap keuntunga yang diperoleh pemilik toko kelontong, sehingga pendapatan yang didapat mengalami perubahan. Karena semakin dekat jarak berdirinya minimarket dengan toko kelontong, pendapatan yang diperoleh akan semakin berkurang karena adanya persaingan antara keduanya. Hal tersebut memicu beberapa pemilik toko kelontong memiliki usaha lain selain toko kelontong. 
Fenomena semakin menjamur jumlah minimarket di sepanjang jalan yang sangat mudah kita jumpai minimarket waralaba dengan jarak beberapa meter dengan toko kelontong bahkan saling berhadap-hadapan antara keduanya, sehingga membuat persaingan antara toko kelontong dengan alfamart. Sementara dalam Perpres No. 112/2007 Pasal 1 Ayat 12 telah dinyatakan bahwa zonasi, yaitu jarak minimarket minimal 1 (satu) km dengan pedagang kios kecil atau toko kelontong.

Namun pada kenyataan saat ini kita dapat menemukan minimarket yang bersebelahan dengan toko kelontong, hal ini sangat berdampak buruk bagi pedagang toko kelontong, semakin dekat jarak antara pedagang enceran dengan minimarket membuat tingkat persaingan diantara keduanya semakin besar sehingga terjadi perubahan pendapatan pedagang toko kelontong.

Kondisi ini harus mendapat penanganan yang serius dari pemerintah karena menyangkut hajat hidup orang banyak. Menurut sekretaris Jendral Asosiasi Pedagang Pasar Seluruh Indonesia (APSI), Ngadiran menyatakan "bahwa perkembangan dan pertumbuhan gerai minimarket saat ini sudah sangat mengkhawatirkan pedagang kelontong. Selain mengalami penurunan pendapatan, banyak pedagang atau warung harus gulung tikar bahkan tidak menutup kemungkinan kondisi seperti ini bisa menyebabkan kecemburuan terhadap pedagang toko kelontong dengan kondisi usaha semakin menurunkan omzet pendapatan.

Hal ini menjadi alasan pentingnya penelitian ini dilakukan yang memiliki untuk tujuan menganalisis baik secara parsial dan simultan pengaruh faktor modal dan lokasi terhadap pendapatan toko kelontong di Kabupaten Aceh Utara.

\section{LANDASAN TEORI}

\section{A. 1. Pengertian Pasar}

Pasar menurut William J. Stanton adalah orang-orang yang mempunyai keinginan untuk puas, uang untuk berbelanja dan kemauan untuk membelanjakannya. Pasar adalah area tempat jual beli barang dengan jumlah penjual lebih dari satu baik yang disebut sebagai pusat perbelanjaan, pasar tradisional, pertokoan, mall, plaza, pusat perdagangan maupun sebutan lainnya.

Pasar Tradisional adalah pasar yang dibangun dan dikelola oleh Pemerintah, Pemerintah Daerah, Swasta, Badan Usaha Milik Negara dan Badan Usaha Milik Daerah termasuk kerjasama dengan swasta dengan tempat usaha berupa toko, kios, los dan tenda yang dimiliki/dikelola oleh pedagang kecil, menengah, swadaya masyarakat atau koperasi dengan usaha skala kecil, modal kecil dan dengan proses jual beli barang dagangan melalui tawar-menawar.

Sedangkan dalam pengertian teori ekonomi pasar adalah suatu situasi dimana pembeli (konsumen) dan penjual (produsen dan pedagang) melakukan transaksi setelah kedua pihak telah mengambil kata sepakat tentang harga terhadap sejumlah (kuantitas) barang dengan kuantitas tertentu yang menjadi objek transaksi. Kedua pihak, pembeli dan penjual, mendapatkan manfaat dari adanya transaksi atau pasar. Pihak pembeli mendapatkan barang yang diinginkan untuk memenuhi dan memuaskan kebutuhannya sedangkan penjual mendapatkan imbalan pendapatan 
untuk selanjutkan digunakan untuk membiayai aktivitasnya sebagai pelaku ekonomi produksi atau pedagang.

1.2. Pembagian Pasar Jenis-jenis pasar dibagi menjadi sebagai berikut:

\section{a. Jenis Pasar Menurut Jenis Barang}

Jenis-jenis pasar menurut jenis barangnya, yaitu beberapa pasar yang hanya menjual satu jenis barang tertentu, misal pasar hewan, pasar sayur, pasar ikan dan Daging serta pasar Loak.

b. Jenis Pasar Menurut Bentuk Kegiatannya

Menurut dari bentuk kegiatannya pasar dibagi menjadi 2 yaitu: pertama, pasar nyata pasar dimana barang-barang yang akan diperjual belikan dan dapat dibeli oleh pembeli, contoh pasar tradisional dan pasar swalayan. Kedua, pasar tidak nyata (abstrak) merupakan pasar dimana para pedagangnya tidak menawar barang-barang yang akan dijual dan tidak membeli secara langsung tetapi hanya dengan menggunakan surat dagangannya saja. Contoh pasar online, pasar saham, pasar modal dan pasar valuta asing.

c. Jenis Pasar Menurut Cara Transaksinya

- Pasar tradisional adalah pasar yang bersifat tradisional dimana para penjual dan pembeli dapat mengadakan tawar menawar secara langsung. Barang- barang yang diperjual belikan adalah barang yang berupa barang kebutuhan pokok.

- Pasar Modern. Pasar modern adalah pasar yang bersifat modern dimana barang-barang diperjual belikan dengan harga pas dan denganm layanan sendiri. Tempat berlangsungnya pasar ini adalah di mall, plaza, dan tempat-tempat modern lainnya. Jenis-jenis Pasar menurut jenis barangnya. Beberapa pasar hanya menjual satu jenis barang tertentu, misalnya pasar hewan, pasar sayur, pasar buah, pasar ikan dan daging serta pasar loak.

d. Jenis Pasar Menurut Keleluasan

Distribusi Menurut keleluasan distribusi barang yang dijual, pasar dapat dibedakan menjadi pasar lokal, pasar daerah, pasar nasional dan pasar internasional.

\section{B. Definisi UMKM dan Usaha Kelontong}

Berdasarkan Undang Undang nomor 20 tahun 2008 usaha mikro adalah usaha produktif milik orang perorangan dan/atau badan usaha perorangan. Usaha kecil adalah usaha ekonomi produktif yang berdiri sendiri, yang dilakukan oleh orang perorangan atau badan usaha yang bukan merupakan anak perusahaan atau bukan cabang perusahaan yang dimiliki.

Usaha Menengah adalah usaha ekonomi produktif yang berdiri sendiri, yang dilakukan oleh orang perorangan atau badan usaha yang bukan merupakan anak perusahaan atau cabang perusahaan. Secara kriteria menurut undangundang tersebut usaha kecil dan menengah mempunyai minimal kekayaan bersih Rp 50.000.000,- . Usaha kecil dan menengah yang banyak dijalani oleh masyarakat adalah diantaranya usaha ritel. Usaha ritel disini salah 
satunya adalah toko kelontong atau usaha penjualan kebutuhan masyarakat sehari-hari. Menurut Kotler (2005) retailing adalah Penjualan barang secara eceran yang meliputi semua aktivitas penjualan barang ataupun jasa pada konsumen akhir yang bersifat pribadi.

Menurut Sujana (2005) retailing adalah penghimpun barang-barang yang dibutuhkan oleh konsumen akhir, sehingga konsumen akan menjadikan toko retail sebagai tempat untuk mendapatkan barang kebutuhannya.

Menurut Utami (2010) retailing adalah perangkat dari suatu aktivitas bisnis yang melakukan penjualan barang-barang maupun jasa kepada konsumen akhir untuk penggunaan konsumsi perseorangan maupun keluarga.

Toko kelontong atau yang biasa disebut dengan warung penyedia barang kebutuhan sehari-hari merupakan usaha mikro yang kepemilikannya dimiliki oleh pribadi dan melakukan penjualan barang yang bersifat melayani pelanggan atau konsumen datang untuk membeli barang tidak dengan mandiri yaitu dengan dilayani langsung oleh pelayan toko kelontong tersebut, dan pada umumnya pada toko kelontong yang skala kecil pelayan toko kelontong adalah sebagai kasir juga.

Berdasarkan definisi pengecer tersebut terdapat beberapa bentuk dari pengecer diantaranya adalah :

1. Toko khusus ( Speciality Store) Toko yang hanya menjual barangbarang khusus atau satu jenis produk pada dagangannya contoh yang dapat kita lihat di Indonesia adalah clothing store atau toko baju merk tersendiri.

2. Toko Serba Ada (Departmen store) Toko yang menjual beberapa produk di dalam usahanya dan barang yang dijual bersifat umum seperti perabotan rumah tangga, kebutuhan rumah sehari-hari.

3. Minimarket Toko yang menjual kebutuhan masyarakat sehari-hari seperti makanan ringan, alat mandi, dan lain-lain namun dalam skala usaha yang kecil serta persebaran toko yang mendekati pemukiman warga.

4. Toko Swalayan (Supermarket) Sama seperti minimarket namun supermarket memiliki skala usaha yang besar dan letaknya berada di keramaian kota, seperti di dalam mall atau mendekati perkantoran. Barang yang dijual di supermarket meliputi kebutuhan masyarakat sehari-hari seperti makanan, perabotan rumah, alat mandi, alat tulis, dan lain-lain.

C. Modal

Salah satu faktor produksi yang tidak kalah pentingnya adalah modal, sebab didalam suatu usaha masalah modal mempunyai hubungan yang sangat kuat dengan berhasil tidaknya suatu usaha yang tela didirikan. Modal adalah semua bentuk kekayaan yang dapat digunakan langsung maupun tidak langsung dalam proses produksi untuk menambah output. Dalam pengertian ekonomi, modal yaitu barang atau uang yang bersama-sama faktor-faktor produksi tanah dan tenaga kerja menghasilkan barang-barang dan jasa-jasa 
baru. Modal atau biaya adalah salah satu faktor yang sangat penting bagi setiap usaha, baik skala kecil, menengah maupun besar.

Modal merupakan input (faktor produksi) yang sangat penting dalam menentukan tinggi rendahnya pendapatan. Tetapi bukan berarti merupakan faktor satu-satunya yang dapat meningkatkan pendapatan. Sehingga dalam hal ini modal bagi pedagang juga merupakan salah satu faktor produksi yang mempengaruhi tingkat pendapatan pedagang.

Didalam suatu usaha masalah modal mempunyai hubungan yang sangat kuat dengan berhasil tidaknya suatu usaha yang telah didirikan. Modal dapat dibagi sebagai berikut yaitu pertam, modal tetap diartikan yang memberikan jasa untuk proses produksi dalam jangka waktu yang relatif lama dan tidak terpengaruh oleh besar kecilnya jumlah produksi. Kedua, modal lancar merupakan modal memberikan jasa hanya sekali dalam proses produksi, bisa dalam bentuk bahan-bahan baku dan kebutuhan lain sebagai penunjang usaha tersebut.

D. Lokasi

Lokasi adalah tempat perusahaan beroperasi atau tempat perusahaan melakukan kegiatan untuk menghasilkan barang dan jasa yang mementingkan segi ekonominya". Lokasi merupakan tempat usaha yang sangat mempengaruhi keinginan seseorang konsumen untuk datang dan berbelanja. ${ }^{1}$ Sedangkan pengertian lokasi menurut Kasmir yaitu Tempat melayani konsumen, dapat pula diartikan sebagai tempat untuk memajangkan barang-barang dagangannya. Lokasi adalah tempat perusahaan beroperasi atau tempat perusahaan melakukan kegiatan untuk menghasilkan barang dan jasa yang mementingkan segi ekonominya. Melihat persoalan dari sisi permintaan (pasar)". Losch mengatakan bahwa "lokasi penjual sangat berpengaruh terhadap jumlah konsumen yang dapat digarapnya. Makin jauh dari tempat penjual, konsumen makin enggan membeli karena biaya transportasi untuk mendatangi tempat penjual semakin mahal. Pemilihan lokasi menurut memilih lokasi usaha yang tepat sangat menentukan keberhasilan dan kegagalan usaha dimasa yang akan datang.

Berdasarkan teori diatas dapat disimpulkan bahwa lokasi merupakan suatu tempat dimana perusahaan beroperasi dan menghasilkan barang dan jasa serta pemilihan suatu lokasi perusahaan sangat menentukan keberhasilan suatu usaha.

Faktor-Faktor yang mempengaruhi lokasi menurut Fandy Tjiptono (2002:92) pemilihan tempat/lokasi fisik memerlukan pertimbangan cermat terhadap faktor-faktor berikut:

1. Akses, misalnya lokasi yang dilalui atau mudah di jangkau sarana transfortasi umum.

2. Visibilitas, yaitu lokasi atau tempat yang dapat dilihat dengan jelas dari jarak pandang normal.

${ }^{1}$ Ujang Suwarman, Perilaku Konsumen, Bogor : PT.Ghalia Indonesia, 2004 h.280 
3. Lalu lintas (traffic), menyangkut dua pertimbangan utama: a. Banyaknya orang yang lalu-lalang bisa memberikan peluang besar terhadap terjadinya buying, yaitu keputusan pembelian yang sering terjadi spontan, tanpa perencanaan, dan atau tanpa melalui usahausaha khusus. b. Kepadatan dan kemacetan lalu lintas bisa juga jadi hambatan.

4. Tempat parkir yang luas, nyaman, dan aman, baik untuk kendaraan roda dua maupun roda empat.

5. Ekspansi, yaitu tersedianya tempat yang cukup luas apabila ada perluasan di kemudian hari.

6. Lingkungan, yaitu daerah sekitar yang mendukung produk yang ditawarkan. Sebagai contoh, restoran/rumah makan berdekatan dengan daerah.

\section{E. Pendapatan}

Pendapatan atau penghasilan itu sama artinya dengan hasil berupa uang atau material lainnya yang dicapai dari penggunaan kekayaan atau jasa-jasa manusia bebas. Menurut Biro Pusat Statistik, pengertian pendapatan dan penerimaan adalah : 1. Pendapatan ialah faktor yang didistribusikan yang dibagi lagi menurut sumbernya menjadi penghasilan sebagai gaji dan upah, penghasilan dari usaha sendiri, pekerjaan bebas dan merupakan imbalan atas penerimaan jasa atau harta milik penghasilan dari kepemilikan harta. 2. Transfer yang bersifat redistributif, terutama terdiri dari transfer pendapatan yang tidak mengikat dan biasanya bukan merupakan imbalan atas penerimaan jasa atau harta milik.

\section{METODOLOGI PENELITIAN}

Penelitian ini merupakan jenis penelitian kuantitatif yang menggunakan teknik perhitungan statistik persamaan regresi liniear berganda. Lokasi penelitian ini dilakukan di Krueng Geukueh Aceh Utara. Jumlah populasi terdiri dari pedagang toko sebanayak 73 orang sehingga sampel yang diambil menggunakan sampel jenuh atau seluruh populasi diambil sebagai sampel penelitian.

Regresi berganda ditujukan dalam memprediksi dan menguji analisis sejauh mana variabel bebas berpengaruh terhadap variabel-variabel terikat. Persamaan model ekonometrika dapat digambarkan sebagai berikut:

$$
Y=a+b_{1} X_{1}+b_{2} X_{2} e
$$

\section{HASIL PENELITIAN}

Uji simultan ini bertujuan untuk menguji atau mengkonfirmasikan hipotesis yang menjelaskan tentang variabel independen (modal dan lokasi) secara bersamasama berpengaruh terhadap variabel dependen (pendapatan). Adapun hasil pengujian $\mathrm{F}$ atau uji simultan dapat dilihat pada tabel di bawah sini:

\section{Tabel.1}

Uji F

ANOVA $^{\mathrm{a}}$ 


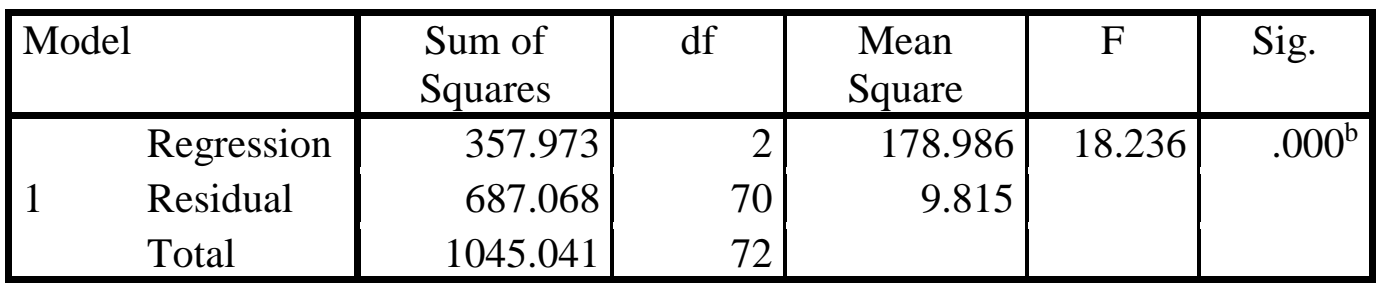

a. Dependent Variable: Pendapatan

b. Predictors: (Constant), Lokasi, Modal

Sumber: Data Primer diolah, 2019

Berdasarkan hasil perhitungan didapatkan $\mathrm{F}$ hitung sebesar 18.236 dengan tingkat signifikan 0,00 , sedangkan nilai $\mathrm{F}_{\text {tabel }}$ berlaku rumus $(\mathrm{k} ; \mathrm{n}-\mathrm{k})$ dimana $\mathrm{k}=2$ dan $\mathrm{n}=73$, maka menghasilkan angka $(2 ; 73-2)=(2: 71) \mathrm{makaF}_{\text {tabel }}=3,13$. Berdasarkan $F_{\text {tabel }}$ yang diperoleh yaitu 3,13, maka $F_{\text {hitung }}>F_{\text {tabel, }}$ yaitu $18.236>3,13$ dan sing $0.000<0,05$, disimpulkan bahwa tolah $\mathrm{H}_{0}$ terima $\mathrm{H}_{\mathrm{aa}}$ artinya variabel independen (modal dan lokasi) secara bersama-sama berpengaruh terhadap variabel dependen (pendapatan).

Selanjutnya uji secara parsial dilakukan untuk mengetahui apakah variabel bebas berpengaruh positif terhadap variabel terikat yang dilihat dari hasil regresi linier berganda. Uji secara parsial dilakukan untuk mengetahui variabel bebas berpengaruh positif terhadap variabel terikat yang dilihat dari hasil regresi linier berganda.

Nilai $\mathrm{t}_{\text {tabel }}$ dilihat berdasarkan ketetapan rumus yaitu: $\mathrm{t}_{\text {tabel }}=\frac{0,05}{2} ; n-k-1$.

Dimana $\mathrm{n}$ jumlah responden dan $\mathrm{k}$ jumlah variabel $\mathrm{X}$.

Dari pernyatan di atas dapat dilihat pada hasil penelitian berikut ini:

Tabel 2

Uji t

\begin{tabular}{|l|r|r|r|r|r|}
\hline \multirow{2}{*}{ Model } & \multicolumn{2}{|c|}{$\begin{array}{c}\text { Unstandardized } \\
\text { Coefficients }\end{array}$} & $\begin{array}{l}\text { Standardized } \\
\text { Coefficients }\end{array}$ & \multirow{2}{*}{ T } & \multirow{2}{*}{ Sig. } \\
\cline { 2 - 4 } & \multicolumn{1}{|c|}{ B } & \multicolumn{1}{c|}{ Std. Error } & \multicolumn{1}{c|}{ Beta } & & \\
\hline \multirow{2}{*}{ (Constant) } & 18.320 & 2.362 & & 7.756 & .000 \\
1 Modal & .206 & .081 & .255 & 2.550 & .013 \\
\multicolumn{1}{|c|}{ Lokasi } & .303 & .065 & .467 & 4.670 & .000 \\
\hline
\end{tabular}

Sumber: Data Primer di olah, 2019

Dilihat dari tabel di atas, data menunjukkan bahwa semua variabel bebas terdapat hubungan terhadap variabel terikat secara parsial dan signifikan yaitu:

a. Pengaruh Modal $\left(\mathrm{X}_{1}\right)$ terhadap pendapatan $(\mathrm{Y})$

Dalam penelitian ini diketahui nilai signifikan thitung modal $\left(\mathrm{X}_{1}\right)$ sebesar 2.550 Jika dibandingkan dengan nilai $\mathrm{t}_{\text {tabel }}=\frac{0,05}{2} ; 73-2-1=0,025 ; 70=1.994$ maka $t_{\text {hitung }}>t_{\text {tabel }}=2.550>1.994$. Dengan demikian berpengaruh positif dan signifikan karena $0,013<0,05$ terhadap pendapatan.

b. Pengaruh Lokasi $\left(\mathrm{X}_{2}\right)$ terhadap Pendapatan $(\mathrm{Y})$ 
Penelitian ini dapat menunjukkan nilai signifikan thitung Lokasi $\left(\mathrm{X}_{2}\right)$ sebesar 4.670 jika dibandingkan dengan nilai $t_{\text {tabel }}=1.994$ maka $t_{\text {hitung }}>t_{\text {tabel }}=4.670>$ 1.994 sehingga dengan demikian berpengaruh positif dan signifikan karena $0,000<0,05$ terhadap pendapatan.

Dari tabel tersebut diperoleh model regresi linear berganda sebagi berikut:

$$
\mathrm{Y}=\mathbf{1 8 . 3 2 0 + 0 . 2 0 6} \mathrm{X}_{\mathbf{1}}+\mathbf{0 . 3 0 3} \mathrm{X}_{\mathbf{2}}
$$

Koefisien-koefisien pada persamaan regresi linier berganda di atas dapat diartikan sebagai berikut:

a. Nilai konstanta model persamaan regresi adalah sebesar 18.320 artinya jika variabel-variabel $\mathrm{X}_{1}$, dan $\mathrm{X}_{2}$, bernilai nol, maka rata-rata pendapatan sebesar 18.320 .

b. Nilai koefisien regresi modal sebesar 0,206 menunjukkan bahwa setiap peningkatan sebesar $1 \%$ satuan, maka Pendapatan akan naik sebesar 20,6\%. Sebaliknya jika Pendapatan mengalami penurunan sebesar $1 \%$ satuan maka modal akan menurun sebesar 20,6\% dapat dikatakan bahwa antara modal dan pendapatan menunjukkan hubungan yang positif.

c. Nilai koefisien regresi lokasi sebesar 0,303 menunjukkan bahwa setiap peningkatan sebesar 1\% satuan, maka pendapatan akan naik sebesar 30,3\%. Sebaliknya jika pendapatan mengalami penurunan sebesar $1 \%$ satuan maka lokasi akan menurun sebesar 30,3\% menunjukkan bahwa antara inovasi dan pendapatan menunjukkan hubungan yang positif.

\section{KESIMPULAN}

Berdasarkan hasil uji regresi berganda menunjukkan variabel modal pengaruh secara positif terhadap tingkat pendapatan pedagang. Hal ini dapat dilihat dari nilai koefisien regresi variabel modal ditemukan nilai t hitung $=2.550$ bahwa modal berpengaruh terhadap tingkat pendapatan pedagang kelontong di Kabupaten Aceh Utara.

Hasil uji pengaruh variabel lokasi terhadap tingkat pendapatan pedagang adalah positif. Hal ini dapat dilihat dari nilai koefisien regresi variabel lokasi ditemukan nilai t hitung $=4.670$. Variabel lokasi berpengaruh terhadap tingkat pendapatan kelontong di Kabupaten Aceh Utara.

Secara simultan ditemukan bahwa $F_{\text {hitung }}>F_{\text {tabel, }}$ yaitu $18.236>3,13$ dan sing $0.000<0,05$, maka dapat disimpulkan bahwa tolah $\mathrm{H}_{0}$ terima $\mathrm{H}_{\mathrm{a}}$ variabel independen (modal dan lokasi) secara bersama-sama berpengaruh terhadap variabel dependen (pendapatan).

\section{Saran}

Penulis memberikan saran terkait hasil penelitian ini yaitu pedagang kelontong disarankan untuk dapat meningkatkan jumlah barang yang terjual dengan melakukan terobosan baru sehingga modal dapat ditingkatkan. 
Bagi pedagang yang masih kekurangan modal dapat memanfaatkan lembaga-lembaga keuangan seperti bank syariah maupun lembaga pembiayaan lain yang bisa membantu meningkatkan modal dalam mengembangkan usahanya.

Selanjutnya saran bagi pemerintah daerah agar mendorong pihak-pihak terkait dengan bisnis waralaba minimarket seperti Indomaret dan Alfamart harus mendapat pantauan oleh pemerintah daerah dan Badan Penanaman Modal Daerah. Pemerintah daerah harus menjaga iklim usaha dalam kaitanya dengan persaingan dengan membuat peraturan yang diperlukan untuk melindungi pedagang kelontong.

\section{DAFTAR PUSTAKA}

Alma, Buchari, (2003), Manajemen Pemasaran dan Pemasaran Jasa, Bandung: Alfabeta.

Aulia Ardhian, (2020), Teori Lokasi August Losch, dalam http://auliaardhian.pdf diakses 20 November 2020.

Bagong, Suyanto, (2002), Metode Penelitian Sosial, Jakarta: Prenada Media Group. Hentiani, Tri, (2012), Analisis Faktor-faktor yang Mempengaruhi Pendapatan Pedagang Informal di Pasar Sentral Medan, Skripsi Ekonomi Pembangunan Universitas Sumatera Utara.

Kasmir, (2009), Pengantar Manajemen Keuangan, Jakarta: Kencana.

Nurfiana, Ike Wahyuni, (2018), Analisis Pengaruh Modal, Jam Kerja dan Lokasi Terhadap Tingkat Pendapatan Pedagang Pasar Mranggen, Skripsi Fakultas Ekonomi dan Bisnis Islam UIN Walisongo, 2018, http://eprints.walisongo.ac.id/7975/1/102411068.pdf

Perpres RI No. 112 Tahun 2007 tentang Penataan dan Pembinaan Pasar Tradisional, Pusat Perbelanjaan dan Toko Modern.

Raharjo, Reza Raditya, (2015), Analisis Pengaruh Keberadaan Minimarket Modern Terhada Kelangsungan Usaha Toko Kelontong Di Sekitarnya, Skripsi Fakultas Ekonomi dan Bisnis Universitas Diponegoro, http://eprints.undip.ac.id/46533/1/06_RAHARJO.pdf

Ridha, Ahmad dan Soraya, (2017), Faktor-Faktor Yang Mempengaruhi Uasaha Kerajinan Tas Aceh di Ulee Madon Kecamatan Muara Batu Kabupaten Aceh Utara,

$\begin{array}{lcc}\text { Jurnal Samudera } & \text { Indonesia, } \\ \text { https://ejurnalunsam.id/index.php/jse/article/view/69/43, h } 87 .\end{array}$

Kotler, Philip, (2005), Manajemen Pemasaran, Jilid 1 dan 2, Jakarta: PT Indeks Kelompok Gramedia.

Gramedia , (2005), Dasar-dasar Pemasaran, Edisi II, PT. Indeks Kelompok Jakarta:

Stanton, William J, (1993), Prinsip Pemasaran, Jakarta: Erlangga, 1993.

Suparmoko, (2012), Ekonomi Lingkungan, Yogyakarta: Penerbit BPFE.

Suwarman, Ujang, (2004), Perilaku Konsumen, Bogor: PT. Ghalia Indonesia.

Tambunan, Tulus, (2002), Usaha Kecil dan Menengah di Indonesia Beberapa Isu Penting, Jakarta: PT Salemba.

Tjiptono, Fandi, (2002), Strategi Pemasaran, Yogyakarta: Penerbit Andi. 